\title{
RADIOCARBON DATING OF THE CRANNOGS OF LOCH TAY, PERTHSHIRE (SCOTLAND)
}

\author{
T N Dixon ${ }^{1} \bullet \mathrm{G} \mathrm{T} \mathrm{Cook}{ }^{2} \bullet$ B Andrian ${ }^{3} \bullet \mathrm{L} \mathrm{S} \mathrm{Garety}^{2} \bullet \mathrm{N} \mathrm{Russell}^{2} \bullet \mathrm{T}_{\text {Menard }}^{2}$
}

\begin{abstract}
Crannogs are ancient artificial islands found in Scotland and Ireland, which typically had some sort of dwelling place constructed on them that served variously as farmers' homesteads, status symbols, refuges in times of trouble, hunting and fishing stations, etc. Substantial research has been carried out for similar sites in mainland Europe, which has demonstrated that they were lakeside settlements, mostly dating to the Neolithic period and not built over open water. In contrast, the Scottish and Irish sites were built in open water, clearly separate from the shore. In Perthshire, some prehistoric crannogs were originally timber-built roundhouses supported on piles or stilts driven into the loch bed. Today, these crannogs appear as treecovered islands or remain hidden as submerged stony mounds. Until recently, there were few radiocarbon dates for these structures and so the sites appeared as a homogeneous group. Not only did this make it impossible to examine them in subgroupings but it also inhibited research, as they did not fit into known periods or architecturally distinct sub-groups, except that they were surrounded by water. Recent work in Loch Tay has resulted in ${ }^{14} \mathrm{C}$ dating of the timber piles from 13 of the 18 crannogs in the loch, allowing them to be fitted into different classes. A major group was constructed in the Early Iron Age around 400-800 BC, with smaller groups constructed around 200-300 BC and $0 \mathrm{BC} / \mathrm{AD}$. There is also evidence of repair/ reoccupation of some of these crannogs in the 6th-9th centuries AD. A number of the sites were also known to be inhabited into the recent past, with one, Priory Island, occupied until the 17th century. The dates of construction also raise important issues relating to the loch-level changes that have taken place. The ${ }^{14} \mathrm{C}$ results will be discussed in relation to the periods of origin and habitation of the crannogs.
\end{abstract}

\section{INTRODUCTION}

Artificial islands have been studied since the 19th century, when Robert Munro carried out considerable work on these throughout Europe (Munro 1882, 1890). Substantial research has subsequently shown that they were lakeside settlements, mainly dating to the Neolithic period (Ruoff 1972; Delgado 1997). In contrast, crannogs, which are artificial islands found in Scotland and Ireland, were built in open water, clearly separate from the shore. Typically, some sort of dwelling place was constructed on them, built of timber or stone, creating a structure that had many potential uses, e.g. defended settlement, farmers' homestead, status symbol, or hunting and fishing station. The crannogs were used from the Early Iron Age, and historical records indicate that some were in use as recently as the 17th century AD. Figure 1 is a schematic representation of an Iron Age crannog, based on the excavated Oakbank Crannog. They are found in lochs of all sizes throughout Scotland, and to date about 500 sites have been noted (Dixon 2004). Figure 2 illustrates the distribution of known crannog sites in Scotland. Few of the 30,000 lochs in Scotland have been surveyed so far, but in Loch Awe, Loch Tay, and Loch Lomond (McArdle et al. 1973; Dixon 1982, 1997, respectively), which have been systematically surveyed, there are a total of 48 crannogs, indicating that throughout the country there are likely to be many more than the 500 recorded so far.

It is very difficult to date these sites by observation alone as they appear in most cases to be large cairns (mounds of stones) or small, tree-covered, stony islands. However, because they are found in the dark, peaty waters of freshwater lochs (lakes), well-preserved timbers are often available for sampling for radiocarbon dating. Furthermore, detailed excavation has shown that they can add sig-

\footnotetext{
'The Scottish Trust for Underwater Archaeology, Dept. of Archaeology, University of Edinburgh, Infirmary Street, Edinburgh EH1 1LT, United Kingdom. Corresponding author. Email: nick.dixon@ed.ac.uk.

${ }^{2}$ Scottish Universities Environmental Research Centre, Scottish Enterprise Technology Park, East Kilbride G75 0QF, United Kingdom.

${ }^{3}$ Scottish Crannog Centre, Kenmore, Loch Tay, Aberfeldy, Perthshire PH15 2HY, United Kingdom.
} 


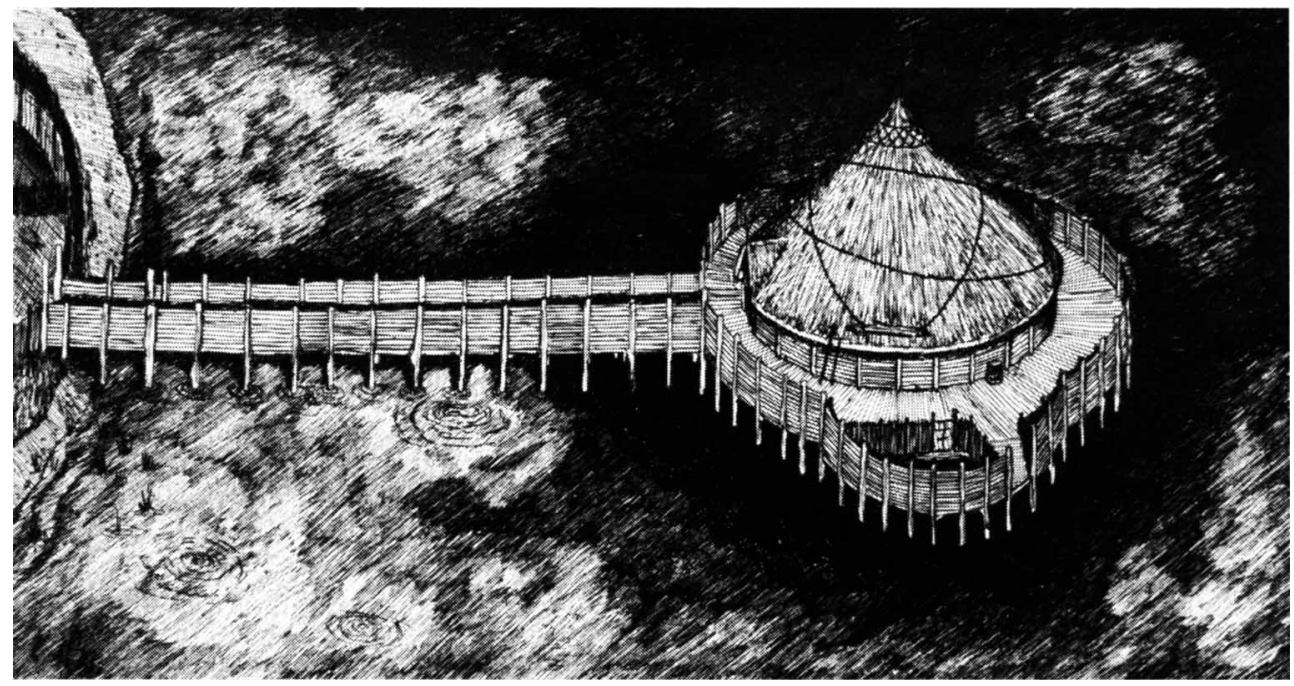

Figure 1 Putative reconstruction of an Iron Age crannog (copyright The Scottish Trust for Underwater Archaeology, STUA).

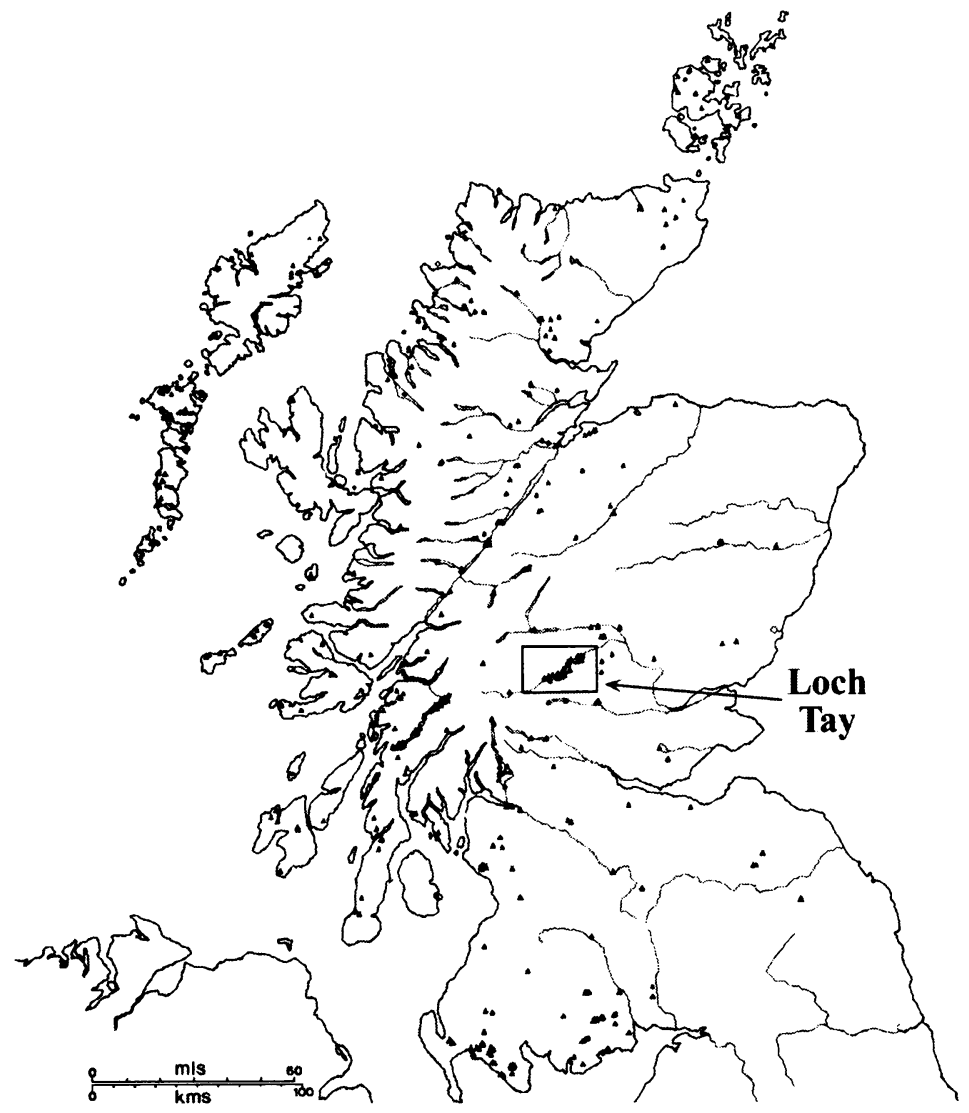

Figure 2 Distribution of known crannog sites in Scotland 
nificantly to our understanding of the prehistoric past, owing to the mass of well-preserved organic material on them. This is not only of significance to crannogs, but can be extrapolated to help clarify the life of nearby shore dwellers.

There are the remains of 18 artificial island dwellings in Loch Tay, which were inhabited by the people who lived in this area over the last 2500 yr (Figure 3) (Dixon 1982). All have been surveyed and examined, first in 1979 and again in 2000 (Dixon 1982, 2004). They are in a superb state of preservation and represent a wide range of site types, ranging from submerged mounds to islands. In 1980,3 of the crannogs were ${ }^{14} \mathrm{C}$ dated using radiometric methods (Table 1). Two analyses of timber samples (GU-1323 and GU-1325) from Oakbank Crannog (site 3 in Figure 3), off the north shore and near the east end of the loch, produced calibrated age ranges of 820-500 BC ( $94.0 \%$ probability) and 760-390 BC (95.4\% probability); while analysis of 1 sample (GU-1322) from Fearnan Crannog (site 4 in Figure 3), $100 \mathrm{~m}$ away, produced a calibrated age range of $770-410 \mathrm{BC}(95.4 \%$ probability). Firbush Crannog (site 11 in Figure 3), off the south shore and near the west end of the loch, had 1 sample (GU-1324) dated to 360-50 BC (95.4\% probability). Further samples from Oakbank Crannog were dated over the next few years (Table 1), all indicating Early Iron Age construction.

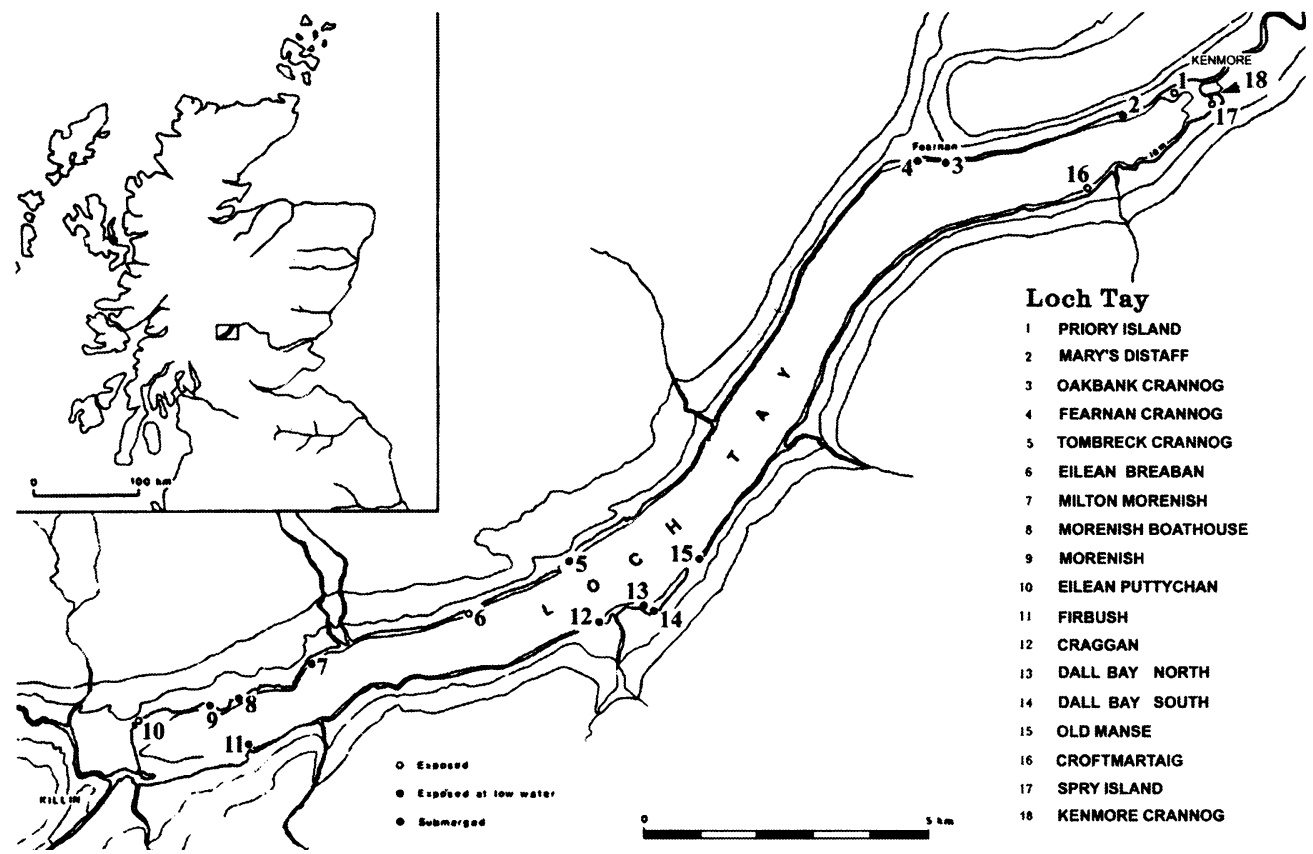

Figure 3 Locations of the Loch Tay crannogs

Oakbank is the most widely excavated crannog in Loch Tay. Its stratigraphy is clear and suggests that it was initially constructed as a free-standing pile dwelling with open water underneath the platform. Here, the remains of an Iron Age house floor have been discovered, which is preserved with bracken and ferns that the crannog dwellers laid down to make the house a comfortable place to live in. Among the bracken and ferns are many of the objects that these people used in their everyday life, including pottery with burnt food still sticking to the inside, wooden plates and dishes, remains of a wooden cup for drinking, a wooden spoon, and a butter dish with remains of butter still sticking to the inside. It is clear from these that the inhabitants relied heavily upon wood to make their domestic utensils. Animal bones, food remains, and sheep droppings with parasite eggs still pre- 
Table 1 Early radiometric ${ }^{14} \mathrm{C}$ analysis of timbers from Oakbank, Fearnan, and Firbush crannogs.

\begin{tabular}{|c|c|c|c|c|c|}
\hline $\begin{array}{l}\text { Sample } \\
\text { code }\end{array}$ & Crannog & $\begin{array}{l}\text { Additional sample } \\
\text { information }\end{array}$ & $\begin{array}{l}{ }^{14} \mathrm{C} \text { age } \\
(\mathrm{BP})\end{array}$ & $\begin{array}{l}\delta^{13} \mathrm{C} \\
(\% o)\end{array}$ & $\begin{array}{l}\text { Calibrated range } \\
(95.4 \% \text { probability) }\end{array}$ \\
\hline GU-1323 & Oakbank (site 3) & Oak: top of crannog mound & $2545 \pm 55$ & -25.9 & $820 \mathrm{BC}(94.0 \%) 500 \mathrm{BC}$ \\
\hline GU-1325 & Oakbank & $\begin{array}{l}\text { Oak: Loch bed, south edge of } \\
\text { crannog }\end{array}$ & $2410 \pm 60$ & -25.8 & $760 \mathrm{BC}(95.4 \%) 390 \mathrm{BC}$ \\
\hline GU-1322 & Fearnan (site 4) & Oak: top of crannog mound & $2475 \pm 55$ & -25.6 & $770 \mathrm{BC}(95.4 \%) 410 \mathrm{BC}$ \\
\hline GU-1324 & Firbush (site 11) & $\begin{array}{l}\text { Oak: basal timbers of crannog } \\
\text { foundation }\end{array}$ & $2140 \pm 55$ & -26.6 & $360 \mathrm{BC}(95.4 \%) 50 \mathrm{BC}$ \\
\hline GU-1463 & Oakbank & $\begin{array}{l}\text { Wood: set into organic matrix } \\
\text { on living floor }\end{array}$ & $2360 \pm 60$ & -23.9 & $800 \mathrm{BC}(91.1 \%) 350 \mathrm{BC}$ \\
\hline GU-1464 & Oakbank & $\begin{array}{l}\text { Wood: set into organic matrix } \\
\text { on living floor }\end{array}$ & $2405 \pm 60$ & -24.5 & $760 \mathrm{BC}(95.4 \%) 390 \mathrm{BC}$ \\
\hline GU-3468 & Oakbank & Oak causeway pile & $2490 \pm 50$ & -26.4 & $790 \mathrm{BC}(95.4 \%) 410 \mathrm{BC}$ \\
\hline GU-3469 & Oakbank & Off-site alder pile & $2560 \pm 50$ & -28.8 & $820 \mathrm{BC}(95.4 \%) 520 \mathrm{BC}$ \\
\hline GU-3470 & Oakbank & Alder structural pile & $2510 \pm 50$ & -28.4 & $800 \mathrm{BC}(91.2 \%) 480 \mathrm{BC}$ \\
\hline GU-3471 & Oakbank & Alder structural pile & $2490 \pm 50$ & -28.3 & $790 \mathrm{BC}(95.4 \%) 410 \mathrm{BC}$ \\
\hline GU-3472 & Oakbank & Off-site alder pile & $2450 \pm 50$ & -24.2 & $770 \mathrm{BC}(95.4 \%) 400 \mathrm{BC}$ \\
\hline
\end{tabular}

served in them have also been found. Agricultural practice is indicated by the discovery of a unique cultivation implement, and the presence of Triticum spelta, an early form of wheat. Around the floor are the upright stakes and piles, still complete with their bark, which supported the walls and roof of the house. Forty oak stumps mark the remains of a walkway that led to the shore. The crannog dwellers used mostly alder for piles, with lesser, but still substantial, amounts of oak, a few elm, and the occasional willow or other species. The dwellers valued hazel for hurdle making and pine for making tapers to light fires. Their knowledge and use of different types of wood for different purposes is being more accurately demonstrated all the time.

Clearly, a great deal of detailed information can be derived from crannog investigations, but if sites stand alone then that information is of limited use. The real benefit is when sites can be grouped chronologically and the mass of data can be compared to show significant trends over an area. However, until 2003, only the 3 sites discussed above had been dated in Loch Tay. The purpose of this study was therefore to date the remaining 15 crannogs to set them in some sort of chronological framework that related each to the other. Of these 15 sites, we were unable to find suitable ${ }^{14} \mathrm{C}$ dating material at 5 sites-Priory Island (site 1 in Figure 3), Mary's Distaff (site 2), Eilean Puttychan (site 10), Spry Island (site 17), and Kenmore Crannog (site 18)-despite examining them on a number of occasions.

\section{METHODS}

Samples are often immediately visible or discovered under a thin layer of loch bed silt or among the stones that cover the sites. The most durable timber is oak, which is sometimes exposed in open water with no protection from silt or stones because it is so hard. Even softer types, such as alder, birch, or hazel, are well preserved under only a few centimeters of silt.

The location of timbers was logged, a sample removed with a panel saw, bagged and labeled underwater. Where a timber was associated with a group of others, it was sometimes necessary to excavate a small trench for access, and in this case the features in the trench were recorded on a plan. Samples from oak timbers were taken from the outer edge of the pile to include the sapwood where possible, while an entire section was taken through short-lived softer samples with $<30$ rings. 
Samples were carefully chosen. Upright piles in the loch bed might have been driven there at any time during the life of the crannog, but if they were associated with other deposits and lateral timbers projecting out from under the mound, then they could relate to early phases of construction. Oak piles projecting through the top of the mound could be from any phase of building, as they can last for hundreds of years and could have been part of the structure throughout its life. However, smaller stakes in the top of the site might show evidence of cutting to a point and could be assumed to relate to the latest preserved phases of occupation. The same applies to crosspieces and lateral timbers on the top, as they could only have been placed deliberately at the level where they are found.

A subsample ( $\sim 50 \mathrm{~g}$ for radiometric and $5 \mathrm{~g}$ for accelerator mass spectrometry [AMS]) was taken from each of the timbers. Cellulose was purified from each wood sample by acid-base-acid (ABA) washing using $1 \mathrm{M} \mathrm{HCl}$ and $1 \mathrm{M} \mathrm{NaOH}$. After rinsing in water at each stage, the samples were then bleached using a solution of sodium chlorite $(5.3 \mathrm{~g})$ and $1 \mathrm{M} \mathrm{HCl}(12.5 \mathrm{~mL})$ in distilled $\mathrm{H}_{2} \mathrm{O}$ $(200 \mathrm{~mL})$ for $72 \mathrm{hr}$. After this time, the bleaching solution was decanted and replaced by a similar solution of half strength $\left(2.65 \mathrm{~g} \mathrm{NaOCl}_{2}\right.$ and $6.25 \mathrm{~mL} 1 \mathrm{M} \mathrm{HCl}$ in $200 \mathrm{~mL}$ distilled $\left.\mathrm{H}_{2} \mathrm{O}\right)$. The samples remained in this solution for $24 \mathrm{hr}$. The solution was decanted and the samples were thoroughly rinsed using reverse-osmosis-quality $\mathrm{H}_{2} \mathrm{O}$ before a further series of ABA washings took place. The extracted cellulose samples were then dried overnight.

For AMS analysis, samples $(\sim 10 \mathrm{mg})$ were combusted overnight at $850{ }^{\circ} \mathrm{C}$ in sealed, evacuated quartz tubes using $\mathrm{CuO}$ as the oxidant and $\mathrm{Ag}$ foil to mop up contaminants (mainly halides). Graphite was prepared by reduction of the resulting $\mathrm{CO}_{2}$ according to the method of Slota et al. (1987), prior to AMS measurement using the SUERC 5MV terminal voltage spectrometer. Measurements were undertaken at $4.5 \mathrm{MV}$ with carbon in the $4+$ charge state.

For radiometric analysis, samples were combusted in pure oxygen. The $\mathrm{CO}_{2}$ produced was purified, converted to acetylene, and then converted to benzene by cyclotrimerization using a chromiumbased catalyst. A fixed weight of benzene was then added to low-potassium borosilicate glass ampoules of $\sim 20 \mathrm{~mL}$ volume, containing PPO and bis-MSB as the primary and secondary scintillants, respectively, and analyzed by the method set out in Begg (1992).

\section{RESULTS AND DISCUSSION}

All the results are presented in Table 2. Lab numbers with a GU- prefix are radiometric measurements; those with a SUERC-prefix are AMS measurements.

Table $2{ }^{14} \mathrm{C}$ age measurements carried out on wood samples from a range of Loch Tay crannogs (2003-2005).

\begin{tabular}{|c|c|c|c|c|c|}
\hline $\begin{array}{l}\text { Sample } \\
\text { code }\end{array}$ & Crannog & $\begin{array}{l}\text { Additional sample } \\
\text { information }\end{array}$ & $\begin{array}{l}{ }^{14} \mathrm{C} \text { age } \\
(\mathrm{BP})\end{array}$ & $\begin{array}{l}\delta^{13} \mathrm{C} \\
(\% o)\end{array}$ & $\begin{array}{l}\text { Calibrated range } \\
(95.4 \% \text { probability) }\end{array}$ \\
\hline SUERC-7315 & $\begin{array}{l}\text { Eilean Breaban } \\
\text { (site 6) }\end{array}$ & $\begin{array}{l}\text { Alder: earlier site } \\
\text { phase }\end{array}$ & $2430 \pm 35$ & -24.0 & $760 \mathrm{BC}(95.4 \%) 400 \mathrm{BC}$ \\
\hline GU-12124 & Eilean Breaban & $\begin{array}{l}\text { Oak: later site } \\
\text { phase }\end{array}$ & $1520 \pm 50$ & -26.0 & $\mathrm{AD} 420(95.4 \%) \mathrm{AD} 640$ \\
\hline GU-12123 & $\begin{array}{l}\text { Milton Morenish } \\
\text { (site 7) }\end{array}$ & Oak: loch bed pile & $2530 \pm 50$ & -24.1 & $810 \mathrm{BC}(93.9 \%) 500 \mathrm{BC}$ \\
\hline SUERC-7305 & Milton Morenish & $\begin{array}{l}\text { Alder: loch bed } \\
\text { pile }\end{array}$ & $2400 \pm 35$ & -24.4 & $750 \mathrm{BC}(95.4 \%) 390 \mathrm{BC}$ \\
\hline SUERC-6487 & $\begin{array}{l}\text { Morenish Boathouse } \\
\text { (site 8) }\end{array}$ & Oak: walkway & $2425 \pm 35$ & -25.2 & $750 \mathrm{BC}(95.4 \%) 400 \mathrm{BC}$ \\
\hline SUERC-6488 & Morenish Boathouse & Alder: walkway & $2400 \pm 35$ & -27.3 & $750 \mathrm{BC}(95.4 \%) 390 \mathrm{BC}$ \\
\hline SUERC-9746 & Morenish Boathouse & $\begin{array}{l}\text { Birch: top of } \\
\text { crannog mound }\end{array}$ & $2055 \pm 35$ & -25.9 & $170 \mathrm{BC}(95.4 \%)$ AD 30 \\
\hline
\end{tabular}


Table $2{ }^{14} \mathrm{C}$ age measurements carried out on wood samples from a range of Loch Tay crannogs (2003-2005). (Continued)

\begin{tabular}{|c|c|c|c|c|c|}
\hline $\begin{array}{l}\text { Sample } \\
\text { code }\end{array}$ & Crannog & $\begin{array}{l}\text { Additional sample } \\
\text { information }\end{array}$ & $\begin{array}{l}{ }^{14} \mathrm{C} \text { age } \\
(\mathrm{BP})\end{array}$ & $\begin{array}{l}\delta^{13} \mathrm{C} \\
(\% o)\end{array}$ & $\begin{array}{l}\text { Calibrated range } \\
(95.4 \% \text { probability) }\end{array}$ \\
\hline SUERC-9747 & Morenish Boathouse & $\begin{array}{l}\text { Hazel: top of } \\
\text { crannog mound }\end{array}$ & $2045 \pm 35$ & -30.7 & $170 \mathrm{BC}(95.4 \%) \mathrm{AD} 30$ \\
\hline SUERC-6491 & Old Manse (site 15) & $\begin{array}{l}\text { Alder ( } \mathrm{S} 1) \text { : in base } \\
\text { of main mound }\end{array}$ & $2460 \pm 35$ & -25.4 & $760 \mathrm{BC}(95.4 \%) 410 \mathrm{BC}$ \\
\hline SUERC-6492 & Old Manse & $\begin{array}{l}\text { Alder (S1): in base } \\
\text { of main mound }\end{array}$ & $2485 \pm 35$ & -25.2 & $780 \mathrm{BC}(90.7 \%) 480 \mathrm{BC}$ \\
\hline SUERC-6493 & Old Manse & $\begin{array}{l}\text { Alder (S2): in base } \\
\text { of main mound }\end{array}$ & $2465 \pm 35$ & -26.9 & $770 \mathrm{BC}(95.4 \%) 410 \mathrm{BC}$ \\
\hline SUERC-6497 & Craggan (site 12) & $\begin{array}{l}\text { Oak (S1): top of } \\
\text { mound }\end{array}$ & $2420 \pm 35$ & -24.9 & $750 \mathrm{BC}(95.4 \%) 390 \mathrm{BC}$ \\
\hline SUERC-7155 & Craggan & $\begin{array}{l}\text { Oak (S1): top of } \\
\text { mound }\end{array}$ & $2500 \pm 35$ & -24.6 & $790 \mathrm{BC}(94.2 \%) 500 \mathrm{BC}$ \\
\hline SUERC-6498 & Craggan & $\begin{array}{l}\text { Oak (S2): top of } \\
\text { mound }\end{array}$ & $1270 \pm 35$ & -26.3 & $\operatorname{AD} 660(92.3 \%)$ AD 830 \\
\hline SUERC-7156 & Craggan & $\begin{array}{l}\text { Oak (S2): top of } \\
\text { mound }\end{array}$ & $1300 \pm 35$ & -25.7 & AD $650(95.4 \%$ AD 780 \\
\hline SUERC-6499 & $\begin{array}{l}\text { Dall Bay South } \\
\text { (site 14) }\end{array}$ & Oak: top of site & $2420 \pm 35$ & -23.4 & $750 \mathrm{BC}(95.4 \%) 390 \mathrm{BC}$ \\
\hline SUERC-6500 & Dall Bay South & Oak: base of site & $2560 \pm 35$ & -26.9 & $810 \mathrm{BC}(95.4 \%) 540 \mathrm{BC}$ \\
\hline SUERC-6502 & $\begin{array}{l}\text { Dall Bay North } \\
\text { (site 13) }\end{array}$ & $\begin{array}{l}\text { Alder (S2): loch } \\
\text { bed level }\end{array}$ & $2400 \pm 35$ & -25.5 & $750 \mathrm{BC}(95.4 \%) 390 \mathrm{BC}$ \\
\hline SUERC-7158 & Dall Bay North & $\begin{array}{l}\text { Alder (S2): loch } \\
\text { bed level }\end{array}$ & $2465 \pm 35$ & -25.4 & $770 \mathrm{BC}(95.4 \%) 410 \mathrm{BC}$ \\
\hline SUERC-6501 & Dall Bay North & $\begin{array}{l}\text { Alder (S1): top of } \\
\text { mound }\end{array}$ & $1245 \pm 35$ & -26.0 & $\operatorname{AD} 670(95.4 \%)$ AD 880 \\
\hline SUERC-7157 & Dall Bay North & $\begin{array}{l}\text { Alder (S1): top of } \\
\text { mound }\end{array}$ & $1330 \pm 35$ & -25.4 & $\operatorname{AD} 640(95.4 \%)$ AD 780 \\
\hline SUERC-7314 & Dall Bay North & $\begin{array}{l}\text { DNT S1: from top } \\
\text { of mound }\end{array}$ & $1435 \pm 35$ & -26.0 & $\operatorname{AD} 560(95.4 \%)$ AD 660 \\
\hline GU-12342 & $\begin{array}{l}\text { Croftmartaig } \\
\text { (site 16) }\end{array}$ & $\begin{array}{l}\text { Alder pile 1: loch } \\
\text { bed level }\end{array}$ & $2230 \pm 50$ & -27.9 & $400 \mathrm{BC}(95.4 \%) 180 \mathrm{BC}$ \\
\hline GU-12343 & Croftmartaig & $\begin{array}{l}\text { Alder pile 2: loch } \\
\text { bed level }\end{array}$ & $2210 \pm 50$ & -30.4 & $400 \mathrm{BC}(95.4 \%) 160 \mathrm{BC}$ \\
\hline GU-12125 & Morenish (site 9) & $\begin{array}{l}\text { Alder: half-way } \\
\text { up mound }\end{array}$ & $1940 \pm 50$ & -29.1 & $50 \mathrm{BC}(93.2 \%)$ AD 180 \\
\hline SUERC-7310 & Morenish & $\begin{array}{l}\text { Alder (S1): top of } \\
\text { mound }\end{array}$ & $1970 \pm 35$ & -24.0 & $50 \mathrm{BC}(92.4 \%) \mathrm{AD} 90$ \\
\hline SUERC-7306 & Morenish & $\begin{array}{l}\text { Alder (S2): side of } \\
\text { mound }\end{array}$ & $1930 \pm 35$ & -25.2 & $40 \mathrm{BC}(95.4 \%) \mathrm{AD} 140$ \\
\hline SUERC-7311 & Morenish & $\begin{array}{l}\text { Alder (S3): base of } \\
\text { mound }\end{array}$ & $1950 \pm 35$ & -25.7 & $40 \mathrm{BC}(95.4 \%) \mathrm{AD} 130$ \\
\hline GU-12126 & Tombreck (site 5) & $\begin{array}{l}\text { Alder: bottom } \\
\text { edge of mound }\end{array}$ & $1950 \pm 50$ & -27.8 & $60 \mathrm{BC}(94.0 \%) \mathrm{AD} 180$ \\
\hline SUERC-7312 & Tombreck & $\begin{array}{l}\text { Alder: top of } \\
\text { mound }\end{array}$ & $1970 \pm 35$ & -26.1 & $50 \mathrm{BC}(92.4 \%) \mathrm{AD} 90$ \\
\hline SUERC-7313 & Tombreck & $\begin{array}{l}\text { Alder: base of } \\
\text { mound }\end{array}$ & $2040 \pm 35$ & -26.5 & $170 \mathrm{BC}(95.4 \%) \mathrm{AD} 50$ \\
\hline SUERC-6487 & $\begin{array}{l}\text { Morenish Boathouse } \\
\text { (site 8) }\end{array}$ & Oak: walkway & $2425 \pm 35$ & -25.2 & $750 \mathrm{BC}(95.4 \%) 400 \mathrm{BC}$ \\
\hline SUERC-6488 & Morenish Boathouse & Alder: walkway & $2400 \pm 35$ & -27.3 & $750 \mathrm{BC}(95.4 \%) 390 \mathrm{BC}$ \\
\hline
\end{tabular}


Eilean Breaban Crannog (site 6), which is near the north bank of the loch, is exposed year round. It is artificial, but an outcrop of natural rock, which can be seen underwater on the west side, has provided a solid foundation. The shore is not very good for agriculture here, unlike the situation with many other crannogs in the loch, but clearly the island was an important settlement in the past. Its function is therefore of particular interest as it may have played a part as a more administrative center. Such a role has been noted in other late crannogs such as Keppoch's Council Isle, a small island in Loch Treig excavated by Ritchie in 1930 and known as a meeting place in the post-Medieval period (Ritchie 1942). A timber sample from the west end of site 6, and related to the supposed earlier phase, gave an Early Iron Age date of $2430 \pm 35$ BP (SUERC-7315), calibrating to 760-400 BC, making it potentially contemporaneous with the Oakbank (site 3) and Fearnan Hotel (site 4) crannogs. A timber sample from the east edge of the site and possibly related to the later part of the structure gave a date of $1520 \pm 50 \mathrm{BP}(\mathrm{GU}-12124)$, which calibrated to AD $420-640$. Thus, the ${ }^{14} \mathrm{C}$ dating evidence supports the idea that the crannog is of 2 occupation phases and places these at least $800 \mathrm{yr}$ apart, but there are also documentary references relating to the site in the 16th century (Gillies 1938:38).

Milton Morenish Crannog (site 7) lies $\sim 50 \mathrm{~m}$ off the north shore, and the top is just exposed when the water level is low. Examination around the periphery of the site at loch bed level brought to light timbers in a number of places and also what appeared to be habitation debris in the form of organic material including charcoal, nuts, twigs, and other vegetation. In addition, there seemed to be ash with flecks of charcoal and burnt bone contained within this deposit. In 1 area, on the south side at loch bed level, an array of piles was uncovered. These were particularly interesting as they were set close together and oak and alder were both represented. A wedge was cut from the top outer edge of a substantial oak pile, producing a ${ }^{14} \mathrm{C}$ age of $2530 \pm 50 \mathrm{BP}$ (GU-12123), or 810-500 cal BC. A second sample, from the west side at loch bed level, produced a date of $2400 \pm 35$ BP (SUERC-7305), or 750-390 cal BC. Again, these ages are very similar to those for Oakbank Crannog.

An environmental sample, taken from the material in which the timbers were embedded, contained a range of material almost identical to that found at Oakbank. Barley, spelt and emmer wheat, and flax, along with typical sorts of weeds clearly point to arable agriculture. Some of the waste evidence suggests that grain was processed on the site. The sample also contained evidence of hazelnuts, raspberries, and brambles, in addition to the remains of heather, bilberries, and, most significantly, cloudberries, which only grow above $700 \mathrm{~m}$, indicating that the inhabitants probably roamed far from the crannogs. Bracken, burnt bone, charcoal, and worked wood all indicated the occupation of the dwelling (Miller 2004).

Morenish Boathouse Crannog (site 8) is associated with an array of timbers leading out from the shore. Two samples, one of oak (SUERC-6487) and the other of alder (SUERC-6488), produced ages that were statistically indistinguishable. The results place this putative walkway in the Early Iron Age ( $750-400 \mathrm{BC}$ ). The crannog site itself is very small ( $10 \mathrm{~m}$ diameter) and very low, standing less than a meter above the loch bed. It is possible that the crannog has silted more heavily than the others in the area, but there is no clear reason why this should be the case. The site is beside rich pasture land, which has been substantially cleared in the past. Possibly, the change in the structure of the landscape and the relatively intensive agricultural use has caused more severe run-off than elsewhere, causing greater silt build-up off the shore. No timbers or other features were initially noted either on the top of the site or around the periphery at loch bed level; however, a small sondage cut through the stones on the top of the mound produced birch and hazel wood samples. Again, these produced ages that were statistically indistinguishable but dating to a somewhat later period, in the Middle Iron Age (170 BC-AD 30). It is possible that the walkway represents an early phase of con- 
struction and the samples from the top are from a later phase of occupation. With further work it may be possible to locate timbers in the deep silt that surrounds the crannog with a view to establishing the date of construction.

Old Manse Crannog (site 15) is $\sim 70$ m directly out from a jetty on the south shore. The mound is roughly rectangular on a NE-SW axis, $22 \mathrm{~m}$ by $14 \mathrm{~m}$, with a bulbous extension to the west, but the top area is roughly circular and towards the east end of the structure. The bulbous extension is $\sim 2.6 \mathrm{~m}$ below the surface and is delimited from the main top area by a band of much smaller stones than those in the rest of the crannog surface. The extension may represent the remains of a pier or other feature. Timbers were discovered on the northwest corner and the west side of the main mound, under the stones near the base of the site, and both from about the same level. Once more, the ages are indistinguishable (all within the range 780-410 BC) and indicate that this was again an Early Iron Age construction.

Craggan Crannog (site 12) is elongated with a N-S axis and is $\sim 15 \mathrm{~m}$ from the end of a pier on the south shore. The crannog is $\sim 30 \mathrm{~m}$ long and $\sim 16 \mathrm{~m}$ across. On the top of the mound, among and projecting from the boulder make-up, were oak timbers, which appeared to be part of the structure. These included horizontal beams and vertical piles. Two samples were taken from the top of the mound as no samples were noted around the base. The dates they produced are notable as they are about 1200 yr apart (SUERC-6497 $=2420 \pm 35$ BP and SUERC-6498 $=1270 \pm 35$ BP), although the timbers were only about $5 \mathrm{~m}$ from each other. Reanalysis confirmed these results (SUERC-7155 = $2500 \pm 35 \mathrm{BP}$ and SUERC-7156 = $1300 \pm 35 \mathrm{BP}$ ). It is possible that early-phase construction oaks project up through the mound with later-phase construction oaks deposited nearby. Again, the early ages indicate initial Early Iron Age construction.

There are 2 crannogs $\sim 50 \mathrm{~m}$ apart and $\sim 50 \mathrm{~m}$ offshore at Dall Farm on the south shore of the loch. The more northerly, Dall Bay North (site 13), lies substantially deeper than Dall Bay South (site 14). Dall Bay South Crannog is $30 \times 24 \mathrm{~m}$ at the base but the top is $22 \times 17 \mathrm{~m}$, sloping from 0.75 to $1.5 \mathrm{~m}$ below the surface. On the top can be seen timbers among and projecting from the stones that constitute at least the outer fabric of the crannog. Between some of the timbers was a scatter of burnt bone in a deposit of organic material apparently consisting of bracken and moss. Examination around the base of the site brought to light a group of timbers in the loch bed, just under the peripheral stones on the east side. Samples were taken from the top and bottom of the site and the ${ }^{14} \mathrm{C}$ results are again consistent with Early Iron Age construction of this crannog.

Dall Bay North Crannog (site 13) is also about $30 \times 24 \mathrm{~m}$. The top of the mound is about $18 \times 13 \mathrm{~m}$, the highest point being $1.5 \mathrm{~m}$ below the surface, sloping down to $3 \mathrm{~m}$. Timbers were discovered on top of the steep-sided mound and at loch bed level on the south side and gave dates about $1200 \mathrm{yr}$ apart. The later date from the top (SUERC-6501: cal AD 670-880) is surprising as the top of this crannog is about a meter deeper than Dall Bay South, which is only about $50 \mathrm{~m}$ away and has a date from the top that is from the Early Iron Age. The late sample from Dall Bay North was matched by a reanalysis of the sample (SUERC-7157: cal AD 640-780), while a further timber taken later for confirmation (SUERC-7314) gave a calibrated range of AD 560-660. The spread of dates from this site is notably similar to those from Craggan Crannog (site 12), which is situated in the next bay to the west. The evidence from these 3 sites (Craggan and Dall North and South), with a wide mix of dates at different depths under the water, suggests that they were all submerged throughout their existence, as exposure above the water would have removed early-phase timbers by erosion.

Croftmartaig Crannog (site 16) is partly exposed all year round, but the exposed area belies the true shape of the structure. The exposed area measures $\sim 25 \mathrm{~m}$ along the long axis, while the whole cran- 
nog is $\sim 42 \mathrm{~m}$ long by $\sim 26 \mathrm{~m}$ wide. The underwater part of the site may represent an early phase of construction and habitation, while the circular part above the water may be a later addition. A similar situation is seen at Eilean Breaban Crannog (site 6) on the other side of the loch. Two timbers, very close together, were sampled from loch bed level on the north side of the site and indicate construction in the Early Iron Age, albeit at a somewhat later period of construction than the previous sites (between 400 and $160 \mathrm{BC}$ ). It was not possible to acquire samples from the upper part.

Morenish Crannog (site 9) is one of the deepest of the Loch Tay crannogs with the top $\sim 1 \mathrm{~m}$ below the surface and the bottom edge from 1.7 to $5.6 \mathrm{~m}$ deep. It is unclear why this crannog should be constructed on such a steep slope of 1 in $4(25 \%)$, when all the others in the loch are on relatively slight slopes, although silting may have changed the profile of the loch bed in this area.

There was no evidence of any timbers or organic material representative of occupation debris around the base of the site. A few stones were moved from the east side about half-way up the mound and some small timbers were exposed. One was taken for ${ }^{14} \mathrm{C}$ dating and a sample of the organic matrix in which the timber was embedded was taken for environmental analysis. The ${ }^{14} \mathrm{C}$ sample (GU-12125) produced an age of $1940 \pm 50 \mathrm{BP}$, which calibrated to $50 \mathrm{BC}-\mathrm{AD} 180$. The environmental sample contained evidence of arable agriculture with barley, spelt wheat, and flax, together with a range of weeds associated with crops. Hazel nuts, raspberries, and brambles show that the crannog dwellers were exploiting the woodlands around them. Other evidence of their habitation of the site was seen in cut woodchips, moss, bracken, charcoal, and burnt bone (Miller 2004). Three further samples from the top, side, and base of the mound were subsequently acquired. These produced very similar ages of $1970 \pm 35 \mathrm{BP}$ (SUERC-7310), calibrated to $50 \mathrm{BC}-\mathrm{AD} 90 ; 1930 \pm 35$ BP (SUERC-7306), calibrated to 40 BC-AD 140; and $1950 \pm 35$ BP (SUERC-7311), calibrated to $40 \mathrm{BC}-\mathrm{AD} 130$, respectively. The close dating sequence suggests a site that had 1 occupation phase, which is somewhat later than the other sites already discussed.

Tombreck Crannog (site 5) is always submerged and is a relatively isolated stony mound with no sign of obvious timbers or organic features. It lies near sloping woodlands but with useful agricultural land nearby. A small trench was cut into the bottom edge of the mound and some small branches were uncovered. They were underneath the stones of the crannog and can be confidently interpreted as part of the original site. A small timber (alder) was taken for ${ }^{14} \mathrm{C}$ dating (GU-12126) and the organic matrix in which it was embedded was sampled for environmental analysis. The ${ }^{14} \mathrm{C}$ age produced a calibrated age range of $60 \mathrm{BC}-\mathrm{AD} 180$. The environmental sample showed clear evidence of occupation in fragments of hazel, possibly the remains of hurdles, bracken, burnt bone, and charcoal (Miller 2004). However, there was no evidence of arable crops or weeds associated with them in the sample. This is notable given the lack of good agricultural land on the shore directly adjacent to the crannog, and may suggest a different function for this site. Subsequently, 2 other samples were taken from both the top (SUERC-7312: $1970 \pm 35 \mathrm{BP}$ ) and bottom (SUERC-7313: $2040 \pm 35 \mathrm{BP}$ ) of the mound. These produced calibrated age ranges of $50 \mathrm{BC}-\mathrm{AD} 90$ and $170 \mathrm{BC}-$ AD 50, respectively. All 3 results are statistically indistinguishable and again indicate a single period of construction, from the same period as Morenish.

As far as the calibrated age ranges allow, it can be deduced that the site of Milton Morenish is contemporary with 8 other crannogs in the loch, including Oakbank Crannog. The fact that the environmental sample from Milton Morenish produced very similar material to that from Oakbank supports the view that both were important places in the landscape of the Early Iron Age, exploiting the nearby agricultural land and the natural resources on the higher land at some distance. Morenish and Tombreck Crannogs, on the other hand, are clearly associated by date and appear to be single-phase 
sites. They have less obvious agricultural evidence than Milton Morenish and Oakbank. Eilean Breaban was previously the only crannog with a known Dark Age settlement phase in the loch, but 2 other sites on the opposite shore at Dall North and Craggan have now produced dates from the 7th-9th centuries $\mathrm{AD}$, indicating reoccupation during the Early Historic period.

There are several other notable issues: Oakbank Crannog used to be considered unique in its Early Iron Age date, but it is now clear that all 13 of the sites dated so far originated in the last half of the 1 st millennium $\mathrm{BC}$ or the 1 st or 2 nd centuries $\mathrm{AD}$. Within that group, it is possible to see divisions, although it must be borne in mind that there are problems with the calibration of ${ }^{14} \mathrm{C}$ ages from the earlier part of the period, which means there is insufficient resolution to define specific habitation or occupation phases. Nine sites range within the period 820-350 BC, 2 within the period 400-50 BC and 2 from $170 \mathrm{BC}-\mathrm{AD} 180$. Three sites have phases of reoccupation during the Dark Ages, Eilean Breaban at about AD 420-640 and the 2 neighboring sites of Dall Bay North and Craggan from about AD 560-880. Notably, all 3 sites appear to have origins in the Early Iron Age.

Eilean Breaban is different from most other crannogs in the loch, except Croftmartaig Crannog. Over the years, it has been suggested that this might be at least a 2-phase site as there is an almost circular area above the surface sitting on a submerged oval platform that extends to the west. This theory is confirmed by the ${ }^{14} \mathrm{C}$ age measurements. A date from the deeper part of the site places it in the Early Iron Age, similar to Oakbank, while the upper part dates to the 5th to 7th century AD. It would be difficult, even with the early date, to suggest that the 2 sites were similarly constructed because Eilean Breaban is a site where there is bedrock in the foundation and it is hard to see how that might relate to a free-standing pile dwelling.

Another site where observation suggests the crannog might not have originated as a free-standing structure is Firbush Crannog. There are 3 layers of timbers that seem to be projecting radially out from the bottom of the site. It is possible here that rafts of timbers may have been sunk on top of each other to create a solid foundation, but this would have taken a substantial weight to keep them down. There are no piles obvious in the loch bed around the site, although that does not mean they are not there. Only 1 timber was sampled from the site (GU-1324: 360-50 BC), so further work and more age measurements are required.

Of the 5 crannogs that remain undated, Mary's Distaff is, in appearance and depth, very similar to the other early sites in the loch, but it has not yet been possible to find suitable timbers for sampling. The site in Kenmore Bay has many visible timbers, but none appear to be in situ as this is an area where driftwood collects on the loch bed. The Marquis of Breadalbane built up Spry Island to its present shape in 1841, and no timbers have yet been noted in situ. Priory Island, at the east end of the loch, and Eilean Puttychan at the west end, are both known to have been inhabited into the recent past, and there are no obvious timbers at the bottom of the mounds that might relate to the date of origin.

Because many of the crannogs were built in the Early Iron Age, calibration of the ${ }^{14} \mathrm{C}$ ages produces a very broad calendar age range due to the flat area or plateau in the calibration curve. However, large oak timbers were used in the primary construction phase of some of the crannogs (in particular Oakbank Crannog). As the next phase in this study, we propose to section some of these timbers into 10-yr spans and undertake high-precision AMS ${ }^{14} \mathrm{C}$ analysis on them in an attempt to wiggle-match them to the master ${ }^{14} \mathrm{C}$ calibration curve. This would provide a better estimate of the felling time of the timbers and therefore the initial construction phase of the crannogs. 


\section{CONCLUSIONS}

Efforts have been made to group crannogs into meaningful categories since the middle of the 19th century, when Robert Munro was the prominent researcher in the field (Munro 1882). More recently, several studies have added to the discussion (Barber and Crone 1993; Henderson 1998; Dixon 2004).

This study has made the interpretation of crannog settlements in Loch Tay much clearer. Of the 18 crannogs in the loch, 9 started life in the Early Iron Age and some of these were reoccupied in the Dark Ages. The other sites from later in the Iron Age, and those from the modern era, show that the tradition of living on artificial islands was part of the culture of the region for at least $2500 \mathrm{yr}$. It is now possible to formulate strategies for the examination of the crannogs of Loch Tay and elsewhere to answer specific archaeological questions.

The single most useful target for the future of crannog research in Scotland must be to acquire ${ }^{14} \mathrm{C}$ dates from as many sites as possible throughout the country, so that the greater understanding of the sites in Perthshire is seen as part of a nationwide program. However, together with samples for ${ }^{14} \mathrm{C}$ dating, it is most important that organic samples from occupation levels are collected wherever possible to increase the data that will improve our understanding of the way of life of the people and to build up a picture of the environmental history of the sites and their surroundings. Clearly, a deeper understanding of sites, with the results that can be achieved from such well-preserved organic material, will also contribute to the overall understanding of settlement patterns as a whole throughout the country.

\section{ACKNOWLEDGMENTS}

The authors acknowledge the aid of the National Trust for Scotland (NTS), Heritage Lottery Fund, Historic Scotland, Scottish National Heritage, and Perth and Kinross Heritage Trust for funding. We would also like to thank NTS coordinators Robin Turner and Derek Alexander, John Atkinson of Glasgow University Archaeological Research Division, and David Strachan and Matthew Shelley. Thanks are also due to the staff of the SUERC Radiocarbon Dating and AMS laboratories for making the ${ }^{14} \mathrm{C}$ measurements.

\section{REFERENCES}

Barber JW, Crone BA. 1993. Crannogs; a diminishing resource? A survey of the crannogs of southwest Scotland and excavations at Buston Crannog. Antiquity 67(256):520-33.

Begg FH. 1992. Anthropogenic ${ }^{14} \mathrm{C}$ in the natural (aquatic) environment [PhD dissertation]. Glasgow: University of Glasgow.

Delgado JP, editor. 1997. The British Museum Encyclopaedia of Underwater and Maritime Archaeology. London: British Museum Press. 480 p.

Dixon TN. 1982. A survey of crannogs in Loch Tay. Proceedings of the Society of Antiquaries of Scotland 112: 17-38.

Dixon TN. 1997. Loch Lomond underwater survey [report]. Helensburgh: Friends of Loch Lomond.

Dixon TN. 2004. The Crannogs of Scotland: An Underwater Archaeology. Port Stroud: Tempus Publishing. $168 \mathrm{p}$.

Gillies WA. 1938. In Famed Breadalbane. Strathtay: Clunie Press. 454 p.
Henderson JC. 1998. Islets through time: the definition, dating and distribution of Scottish crannogs. Oxford Journal of Archaeology 17(2):227-44.

McArdle CM, McArdle TD, Morrison IA. 1973. Notes: Scottish lake-dwelling survey: archaeology and geomorphology in Loch Awe, Argyllshire. International Journal of Nautical Archaeology 2(2):381-2.

Miller J. 2004. Preliminary botanical assessment of three crannogs in Loch Tay-Morenish; Milton Morenish; Tombreck [report]. GUARD Project 1802 report. Glasgow: University of Glasgow.

Munro R. 1882. Ancient Scottish Lake-Dwellings or Crannogs. Edinburgh: David Douglas.

Munro R. 1890. The Lake-Dwellings of Europe. London: Cassell \& Co. 600 p.

Ritchie J. 1942. The lake-dwelling or crannog in Eaderloch, Loch Treig: its traditions and its construction. Proceedings of the Society of Antiquaries of Scotland 76:8-78.

Ruoff U. 1972. Palafittes and underwater archaeology. 
In: Underwater Archaeology: a Nascent Discipline. Paris: UNESCO [United Nations Educational, Scientific and Cultural Organization]. p 123-38.
Slota Jr PJ, Jull AJT, Linick TW, Toolin LJ. 1987. Preparation of small samples for ${ }^{14} \mathrm{C}$ accelerator targets by catalytic reduction of CO. Radiocarbon 29(2):303-6. 